\title{
Serological and Molecular Epidemiological Study on Ruminant Brucellosis in Matrouh Province, Egypt
}

\author{
Ibrahim M. Rabah ${ }^{1 *}$, Mohamed A. Nossair ${ }^{2}$, Mohamed M. Elkamshishi ${ }^{1}$ and Eman Khalifa $^{3}$ \\ ${ }^{1}$ Department of Animal Hygiene and Zoonoses, Faculty of Veterinary Medicine, Matrouh University, Egypt \\ ${ }^{2}$ Department of Animal Hygiene and Zoonoses, Faculty of Veterinary Medicine, Alexandria University, Egypt \\ ${ }^{3}$ Department of Microbiology, Faculty of Veterinary Medicine, Matrouh University, Egypt \\ *Corresponding author: ibrahim.rabah@mau.edu.eg
}

\begin{tabular}{|c|c|c|}
\hline Article History: $21-323$ & Received: 02-Jun-21 & Accepted: 17-Jul-21 \\
\hline \multicolumn{3}{|l|}{ ABSTRACT } \\
\hline $\begin{array}{l}\text { A cross-sectional study w } \\
\text { farm animals including ce } \\
\text { using Rose Bengal plate ( } \\
\text { test. Multiplex PCR was } \\
\text { Statistical analysis was ap } \\
\text { farm animals by RBPT, B } \\
\text { significant association bet } \\
\text { was recorded in goats (14 } \\
\text { females were more affect } \\
\text { cattle were more suscepti } \\
\text { goat flocks. There was an } \\
\text { be placed on improving tl } \\
\text { The public health importa } \\
\text { to fight against humans an }\end{array}$ & $\begin{array}{l}\text { onducted in Matrouh governorate, Egypt from July } 2 \\
(\mathrm{n}=50) \text {, sheep }(\mathrm{n}=180) \text {, and goats }(\mathrm{n}=270) \text { were ex } \\
\text { PT) test, buffered acidified plate antigen test (BAPA } \\
\text { ried out as a further confirmatory test for the dete } \\
\text { d using Chi }{ }^{2} \text { and SPSS } 16.0 \text { statistics. The overall pr } \\
\text { AT, CFT, and PCR were } 11.8,10.2,9.4 \text {, and } 8.6 \% \text {, } \\
\text { en recorded rates. Based on the results of RBPT, it w } \\
\% \text { ), followed by sheep }(8.89 \%) \text { and lastly cattle (6\% } \\
\text { han males and older sheep were more susceptible to } \\
\text { than adult. Conclusively, brucellosis is alarming in } \\
\text { gnt need for conducting a proper brucellosis control } \\
\text { inimal health delivery system in large provinces that } \\
\text { of brucellosis was discussed, and it is always urgent } \\
\text { nimals' infectious diseases. }\end{array}$ & $\begin{array}{l}\text { March } 2020 \text {. A total of } 500 \\
\text { erologically for brucellosis } \\
\text { omplement fixation (CFT) } \\
\text { specific genes of Brucella. } \\
\text { of brucellosis in examined } \\
\text { ely with a statistically non- } \\
\text { that the highest prevalence } \\
\text { dition, it was observed that } \\
\text { while younger goats and } \\
\text { rovince particularly within } \\
\text { and a greater focus should } \\
\text { orders with other countries. } \\
\text { place an integrated strategy }\end{array}$ \\
\hline
\end{tabular}

Key words: Brucellosis, Ruminant, Serology, PCR, Seroprevalence.

\section{INTRODUCTION}

Brucellosis disease is a zoonotic infection caused by the species Brucella. The disease is an ancient disease that has been known under various names, including gastric remittent fever, Mediterranean fever, undulant fever, Malta fever, Bang's disease, and Rock fever of Gibraltar. Humans are accidental hosts; but brucellosis remains a major public health issue across the globe and is the most common zoonosis (Diab et al. 2018; Sotnikov et al. 2019).

In Mediterranean and Middle East countries, the disease causes severe obstacles giving rise to significant economic losses in livestock farmers through interference with the breeding programs by decreasing reproductive performance, abortion, decrease feed intake, decrease milk yield and also has a serious influence on public health (Abdelbaset et al. 2018). Edematous and granulomatous lesions were detected in different organs in the body of infected animals particularly in the lungs. Although B. Melitensis distributed in various organs of goats, acute infection did not lead to clinical symptoms. (Shahzad et al. 2018).

In spite of an ongoing effort to control brucellosis, which poses a major threat to public health, it is still endemic in the vast majority of countries in the Middle East, accused of 10,000 new cases a year (Patel et al. 2017). Brucellosis is caused by small, Gram-negative, non-spore former, coccobacillus bacteria of the genus Brucella (Baek et al. 2003). The dairy animals e.g. sheep, goats, and cattle are considered the main reservoirs of infection (Adam and Moss 1995). In dairy animals, uterine outflows and placental discharges from infected animals are the primary sources of infection for both human and animal. Brucella centralizes in supramammary lymph nodes which continue to excrete them in the milk (Refai 2003).

The most common routs of transmission of human brucellosis are direct contact with discharges from the infected placenta and uterus, inhaling of aerosols, intercourse and consumption of unpasteurized dairy

Cite This Article as: Rabah IM, Nossair MA, Elkamshishi MM and Khalifa E, 2022. Serological and molecular epidemiological study on ruminant brucellosis in Matrouh Province, Egypt. International Journal of Veterinary Science 11(1): 82-90. https://doi.org/10.47278/journal.ijvs/2021.076 
products. Common often symptoms are undulant fever for 14 days, tiredness, sweating, weight loss, headache, hepatomegaly, splenomegaly, night sweats, and articular pain. A number of cases may have testicular or bone abscess formation, neurological complications, and endocarditis (Corbel 2006).

Animal management problems, poor hereditary genetics, lack of acceptable animal health service, and nutritional deficiency were the major factors predisposing the disease occurrence (Welay et al. 2018). Animal attendants and farmers who lack the personal hygiene, biosecurity, knowledge of the disease and have a low level of education have a high prevalence of the disease and more susceptible for disease transmission (Arif et al. 2018).

Brucellosis is primarily diagnosed by serological laboratory tests as Rose Bengal Plate (RBPT) Test or Plate Agglutination (PAT) Test as rapid screening field tests. Conventional serological tests like complement fixation test (CFT) and Rivanol test are conducted as confirmational tests for disease diagnosis carried out in central diagnostic laboratories (Morata et al. 2003).

Control programs for brucellosis in Egypt have used two methods: the slaughter of infected animals with positive serologic results and vaccination of the reminder animals within the farm. The policy of testing and slaughter has been widely practiced on a large scale in Egypt where the application of the slaughtering policy of positive animals together with massive administration of $B$. abortus strain 19 immunization of young females led to a drastic decrease in overall sero-reactor levels in Egypt (Haggag et al. 2016). The problem of accurately detecting carrier animals is still considered a major limitation of these programs.

Researches have shown that the national program under existing regulations is ineffective in controlling brucellosis in animals in Egypt (Eltholth et al. 2017). To improve the efficiency of brucellosis-specific prophylaxis, immediate detection of brucellosis by highly specific and sensitive methods is needed. Specific assessments of disease prevalence are the cornerstone for implementing and investigating the effectiveness of any control program (Saeed et al. 2019).

The Aim of the present research was to investigate the occurrence of brucellosis in farm animals in the Matrouh Province, Egypt using serological and molecular testing beside study the effect of some epidemiological factors associated with infection in ruminant.

\section{MATERIALS AND METHODS}

\section{Ethical Approval}

This study has prior approval from Institutional Animal Care and Use Committee (ALEXU-IACUC), Alexandria University, Egypt, member of ICLAS. Approval number: AU 00520190715 MS (1) 01.

\section{Study Area and Period}

The study was carried out in the Matrouh Province (Fig. 1), Egypt for a period of 9 months from July 2019 to March 2020. The study population consisted of farm animals (cattle, sheep, and goats). All samples were analyzed in the laboratory of Department of Microbiology at Faculty of Veterinary Medicine, Matrouh University, Egypt.

\section{Samples}

In total, 500 serum specimens were randomly selected from individually owned ruminant animals (50 from cattle, 180 from sheep, and 270 from goats). Approximately $5 \mathrm{~mL}$ of blood samples were collected in a sterile tube in an aseptic manner $(2 \mathrm{~mL}$ in a plain tube for serological tests and $3 \mathrm{~mL}$ in a tube having $5 \mu \mathrm{L}$ EDTA anticoagulant for molecular diagnosis) and the full history of each animal was recorded including sex, age, season, locality, and animal breeds.

For obtaining serum, the samples were left for $1 / 2 \mathrm{hr}$ at ambient temperature to coagulate then centrifuged at 3000 rpm until $15 \mathrm{~min}$. After that, the clear serum was obtained by using sterile Pasteur pipettes then kept in Eppendorf tubes and labeled. All the serum specimens were kept at $-20^{\circ} \mathrm{C}$ until analyzed. A Description of serum samples collected from farm livestock in Matrouh Province was tabulated in Table 1.

\section{Serological Testing}

Rose Bengal Plate Test (RBPT) was carried out according to Aldomy et al. (2009). This is a Rose Bengal-stained $B$. abortus strain 99 cells in lactate buffer. It was obtained from VSVRI, Abbassia, Cairo, Egypt. It is a rapid slide agglutination test developed for the direct detection of Brucella antibodies in sera of animals and humans. The bacterial suspension is reactive with both immunoglobulin $\mathrm{M}$ and immunoglobulin $\mathrm{G}$ antibodies being the later detected earlier (sub-clinical infections) and over a large period during the disease (chronic stage). The procedures are performed by testing the buffered suspension of $B$. abortus strain colored with Rose Bengal against unknown sera. The absence or presence of a visible agglutination indicates the absence or presence of antibodies in the tested samples.

Buffered Acidified Plate Antigen Test (BAPAT) has been performed according to Farahat et al. (2019). The antigen is prepared from a concentrated cell suspension of $\mathrm{CO}_{2}$ independent smooth strain of B. abortus (Strain 99) The cells are stained with crystal violet and brilliant green stain and suspended in buffered Brucella antigen diluent ( $\mathrm{pH}$ 3.65). It was obtained from VSVRI, Abbassia, Cairo, Egypt. The BAPAT is a rapid slide agglutination procedure developed for the direct detection of Brucella antibodies in sera of humans and animals.

The bacterial suspension is reactive with both immunoglobulin $M$ and immunoglobulin $G$ antibodies being the later detected earlier (sub-clinical infections) and over a large period during the disease (chronic stage). The assay is performed by testing the buffered suspension of $B$. abortus (Strain 99) colored with crystal violet and brilliant green stain against unknown sera. The absence or presence of a visible agglutination indicates the absence or presence of antibodies in the tested samples.

Complement Fixation Test (CFT) was carried out according to Wanger et al. (2017). Components obtained from VSVRI, Abbassia, Cairo, Egypt includes Sheep RBCs suspension (5\% suspension of washed sheep RBCs), Hemolysin (rabbit anti-sheep RBCs antibody), and Guinea pig complement, free of antibodies to the agent of interest. The complement system is a system of serum proteins that react with antigen-antibody complexes. If this reaction occurs on a cell surface, it will result in the formation of transmembrane pores and therefore destruction of the cell. 
The test consists of two procedures: The first is an antigen; test serum and complement are mixed and incubated. The second procedure is an indicator system that consists of sheep red blood cells (SRBC). If the tested serum contains antibodies against Brucella, an antigen-antibody complex is formed; the complement is consumed up and no lysis of SRBC occurs. If the tested serum does not contain antibodies against Brucella (negative reaction), the complement will not be fixed, and lysis of SRBC would occur.

\section{Molecular Studies}

Positive RBPT samples were tested for further confirmation using a PCR assay that targeting the bcsp31 gene specific for genus Brucella, IS711 element of the alkB gene particular for B. abortus, and IS711 element downstream of BMEI1162 specific for B. melitensis (Probert et al. 2004).

\section{DNA Extraction using QIA amp DNA Mini Kit}

Extraction of DNA from blood was carried out according to the technique recommended by O'Leary et al. (2006) where EDTA was added to blood samples that were obtained, and DNA was extracted by using QIAamp DNA Mini Kit. Into the bottom of a $1.5 \mathrm{~mL}$ micro-centrifuge tube, $20 \mu \mathrm{L}$ protease was pipetted. To this $1.5 \mathrm{~mL}$ microcentrifuged tube, $200 \mu \mathrm{L}$ of the sample were added followed by the addition of $200 \mu \mathrm{L}$ AL buffer. The mixture was well mixed by pulse vortexing for $15 \mathrm{sec}$. About $200 \mu \mathrm{L}$ ethanol (96-100\%) was added to the sample and mixed again by pulse vortexing for $15 \mathrm{sec}$. The mixture was carefully pipetted onto the QIAamp Mini spin column (in a $2 \mathrm{~mL}$ collecting tube) without wetting the rim. The cap was closed, and centrifuged at $8000 \mathrm{rpm}$ for $1 \mathrm{~min}$. The QIAamp mini spin column was placed in a new $2 \mathrm{~mL}$ collection tube, and the tube containing the filtrate was discarded. The QIAamp mini spin column was carefully opened and $500 \mu \mathrm{L}$ AW1 buffer was added and centrifuged. Then placed in a clean $2 \mathrm{~mL}$ collection tubes and the tube containing the filtrate were discarded. AW2 buffer $(500 \mu \mathrm{L}$ was added to the mini spin column. Then it was placed in a new $2 \mathrm{~mL}$ collection tube and the old collection tube was discarded with the filtrate. The eluted DNA was stored at $20^{\circ} \mathrm{C}$ till use.

\section{Oligonucleotide Primers for Detection of Brucella}

The target genes, sequence of the used primers and band sizes were tabulated in Table 2 .

\section{Cycling Condition of PCR}

Gently vortex and briefly centrifuge $2 \mathrm{x}$ multiplex PCR kit Qiagen after thawing. PCR reaction was initially optimized by using varying concentrations of molecular biological chemicals and varying cycling conditions. The reaction mixture was mixed gently by vortexing and spinning. In the end, $5 \mu$ l of DNA extracted from a different sample was added. PCR tubes were transferred and then placed in a thermocycler (BioRad). The PCR product is taken and undergoes agarose gel electrophoresis. Description of cycling conditions was presented in Table 3.

\section{Statistical Analysis}

The statistical analysis was carried out using the $\mathrm{Chi}^{2}$ test to study the significant differences in the detection rate
Table 1: Description of serum samples collected from farm animals in Matrouh Province

\begin{tabular}{llllll}
\hline Species & $\mathrm{n}$ & \multicolumn{3}{c}{ Sex group } & \multicolumn{2}{c}{ Age Group (years) } \\
\cline { 3 - 6 } & & Male & Female & $1-<5$ & $5-<10$ \\
\hline Cattle & 50 & 13 & 37 & 30 & 20 \\
Sheep & 180 & 72 & 108 & $1-<2$ & $2-<3 \geq 3$ \\
& & & & 23 & 44 \\
Goats & 270 & 68 & 202 & $1-<4$ & $4-<8 \geq 8$ \\
& & & & 93 & $156 \quad 21$ \\
\hline
\end{tabular}

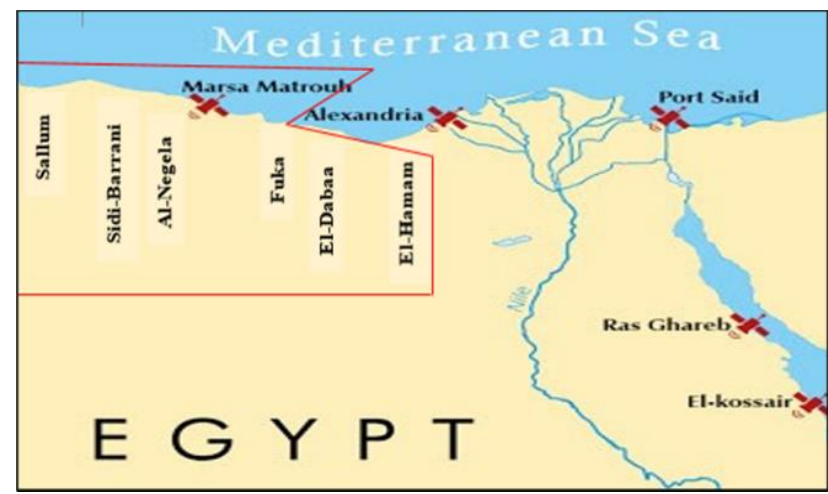

Fig. 1: Different localities in Matrouh Province where animal samples and human samples were collected.

of antibodies among different groups studied according to SPSS 16.0 according to Norusis (2008). A probability value $\mathrm{P}<0.05$ was considered significant statistically.

\section{RESULTS}

The findings, as illustrated in Table 4 , indicated that the seroprevalence of brucellosis in farm animals by different serological tests including RBPT, BAPAT, and CFT was $11.8,10.2$ and $9.4 \%$, respectively, While the result was $8.6 \%$ by PCR. The results in Table 5 illustrated that the highest rate of infection with $B$. abortus was observed in cattle $(33.3 \%)$. At the same time, the highest infectivity with $B$. melitensis was observed in sheep, and goats (62.5 and $65 \%$, respectively).

The obtained results as shown in Table 6 and Fig. 3 showed that the sensitivity of BAPAT, CFT, and PCR in the diagnosis of brucellosis in farm animals was 88.4, 81.16 , and $75.36 \%$, respectively, while the specificity of all tests was $100 \%$ as compared with that of the RBPT. The results that are shown in Table 7 illustrated that the seroprevalence of brucellosis in cattle was $7.69 \%$ for males and $5.41 \%$ for females by RBPT, while that of sheep and goats were $(6.94-10.2 \%)$ and $(13.24-15.35 \%)$ for both males and females, respectively.

The obtained results as shown in Table 8 showed a higher seroprevalence of brucellosis among younger cattle where it was $6.67 \%$ and the smallest group of goats where the prevalence was $22.58 \%$. On the other hand, it was higher in the older group of sheep where the prevalence was $9.73 \%$. $\mathrm{Chi}^{2}$ analysis of the obtained results showed that the total $\mathrm{Chi}^{2}$ value $=15.174$ that was significant at $(\mathrm{P}<0.05)$. The obtained results as illustrated in Table 9 showed that the highest seroprevalence of brucellosis in farm animal species by RBPT was $19.4 \%$ for goats in El-Dabaa, while the higher prevalence in cattle $(16.7 \%)$ was observed in El-Hamam and SidiBarrani for sheep (14.3\%). 
Int J Vet Sci, 2022, 11(1): 82-90.

Table 2: The target genes, sequence of the used primers, and the band sizes

\begin{tabular}{llcc}
\hline Target gene & Oligonucleotide sequence $\left(5^{\prime} \rightarrow 3^{\prime}\right)$ & Band size $(\mathrm{bp})$ & Reference \\
\hline bcsp31, Brucella spp. $(\mathrm{F})$ & 5' GCTCGGTTGCCAATATCAATGC '3 & 223 & Zerva et al. (2001) \\
bcsp31, Brucella spp. $(\mathrm{R})$ & 5' GGGTAAAGCGTCGCCAGAAG '3 & & \\
BMEI1162 gene, B. melitensis $(\mathrm{F})$ & 5' AACAAGCGGCACCCCTAAAA '3 & 279 & Mutnal et al. (2007) \\
BMEI1162 gene, B. melitensis $(\mathrm{R})$ & 5' CATGCGCTATGATCTGGTTACG '3 & & \\
alkB gene, B.abortus $(\mathrm{F})$ & 5' GCGGCTTTTCTATCACGGTATTC '3 & 495 & Song et al. (2019) \\
alkB gene, B.abortus $(\mathrm{R})$ & 5' CATGCGCTATGATCTGGTTACG '3 & & \\
\hline
\end{tabular}

Table 3: Description of cycling conditions of multiplex PCR

\begin{tabular}{lccc}
\hline Steps & Temperature $\left({ }^{\circ} \mathrm{C}\right)$ & Duration & No. of cycles \\
\hline Initial PCR Denaturation step & 95 & $3 \mathrm{~min}$ & 1 hold \\
Denaturation & 95 & $90 \mathrm{sec}$ & 35 cycles \\
Primer annealing & 65 & $1 \mathrm{~min}$ & \\
Extension & 72 & $2 \mathrm{~min}$ & \\
Final extension & 72 & $5 \mathrm{~min}$ & 1 hold \\
Cooling & \multicolumn{3}{c}{ Hold at $4{ }^{\circ} \mathrm{C}$ till further processing } \\
\hline
\end{tabular}

Table 4: Seroprevalence of brucellosis in farm animals in Matrouh Province as examined by different serological tests

\begin{tabular}{|c|c|c|c|c|c|c|c|c|c|}
\hline \multirow[t]{2}{*}{ Farm animals } & \multirow[t]{2}{*}{ No. of samples } & \multicolumn{2}{|c|}{ RBPT } & \multicolumn{2}{|c|}{ BAPAT } & \multicolumn{2}{|c|}{ CFT } & \multicolumn{2}{|c|}{ PCR } \\
\hline & & $+\mathrm{ve}$ & $\%$ & $+\mathrm{ve}$ & $\%$ & $+\mathrm{ve}$ & $\%$ & $+\mathrm{ve}$ & $\%$ \\
\hline Cattle & 50 & 3 & 6.0 & 2 & 4.0 & 2 & 4.0 & 1 & 2.0 \\
\hline Sheep & 180 & 16 & 8.89 & 14 & 7.78 & 13 & 7.2 & 12 & 6.67 \\
\hline Goats & 270 & 40 & 14.81 & 35 & 12.96 & 32 & 11.85 & 30 & 11.11 \\
\hline Total & 500 & 59 & 11.8 & 51 & 10.2 & 47 & 9.4 & 43 & 8.6 \\
\hline $\begin{array}{l}\text { Chi }{ }^{2} \text { value } \\
\text { Total } \mathrm{Chi}^{2} \text { valu }\end{array}$ & & $\chi^{2}=5$. & $\mathrm{P}=0.120$ & $\chi 2=5.5$ & $\begin{array}{r}=0.137 \mathrm{~N} \\
\chi 2=14\end{array}$ & $\begin{array}{l}\chi 2=4.6 \\
8 ; \mathrm{P}=0.2\end{array}$ & $0.198 \mathrm{NS}$ & $\chi 2=5.7$ & $=0.123 \mathrm{NS}$ \\
\hline
\end{tabular}

Table 5: Molecular characterization of animal's seropositive samples as tested by multiplex PCR in Matrouh Province

\begin{tabular}{lcccccc}
\hline Brucella spp. & \multicolumn{4}{c}{ Farm animals } \\
\cline { 2 - 7 } & \multicolumn{2}{c}{ Cattle $(\mathrm{n}=3)$} & \multicolumn{2}{c}{ Sheep $(\mathrm{n}=16)$} & \multicolumn{2}{c}{ Goats $(\mathrm{n}=40)$} \\
\cline { 2 - 7 } & $+\mathrm{ve}$ & $\%$ & $+\mathrm{ve}$ & $\%$ & $+\mathrm{ve}$ & $\%$ \\
\hline B. abortus only & 1 & 33.3 & 0 & 0.0 & 0 & 0.0 \\
B. melitensis only & 0 & 0.0 & 10 & 62.5 & 26 & 65.0 \\
B. abortus and B. melitensis & 0 & 0.0 & 2 & 12.5 & 4 & 10.0 \\
Positive samples for genus brucella & 1 & 33.3 & 12 & 75.0 & 30 & 75.0 \\
Chi $^{2}$ value & & & $\chi 2=40.689 ; \mathrm{P}=0.000$ &
\end{tabular}

Table 6: Diagnostic accuracy of BAPAT, CFT, and PCR in comparing with RBPT as a gold standard technique

\begin{tabular}{llllll}
\hline Test & \multicolumn{1}{c}{ Sensitivity $\%$} & Specificity $\%$ & PPV $\%$ & NPV\% & AUC \\
\hline BAPAT & $88.40(77.89-94.51)$ & $100(99.1-100)$ & $10.17(7.92-12.94)$ & $89.83(87.1-92.1)$ & $0.942(0.898-0.986)$ \\
CFT & $81.16(69.58-89.2)$ & $100(99.1-100)$ & $9.33(7.18-12.02)$ & $90.67(87.98-92.8)$ & $0.906(0.851-0.961)$ \\
PCR & $75.36(63.26-84.60)$ & $100(99.1-100)$ & $8.67(6.61-11.28)$ & $91.33(88.72-93.4)$ & $0.877(0.815-0.938)$ \\
\hline
\end{tabular}

In parenthesis are $95 \%$ CI values.

Table 7: Sex-based seroprevalence of brucellosis in farm animals in Matrouh Province as examined by RBPT

\begin{tabular}{|c|c|c|c|c|c|c|c|c|c|}
\hline \multirow[t]{2}{*}{ Sex } & \multicolumn{3}{|c|}{ Cattle } & \multicolumn{3}{|c|}{ Sheep } & \multicolumn{3}{|c|}{ Goats } \\
\hline & No. & $+v e$ & $\%$ & No. & $+\mathrm{ve}$ & $\%$ & No. & $+\mathrm{ve}$ & $\%$ \\
\hline Males & 13 & 1 & 7.6 & 72 & 5 & 6.9 & 68 & 9 & 13.2 \\
\hline Females & 37 & 2 & 5.4 & 108 & 11 & 10.2 & 202 & 31 & 15.3 \\
\hline Total & 50 & 3 & 6.0 & 180 & 16 & 8.89 & 270 & 40 & 14.81 \\
\hline $\begin{array}{l}\text { Chi }^{2} \\
\text { Total } \mathrm{Chi}^{2}\end{array}$ & \multicolumn{3}{|c|}{$\chi^{2}=0.089 ; \mathrm{P}=0.765$} & \multicolumn{3}{|c|}{$\begin{array}{l}\chi 2=0.560 ; \mathrm{P}=0.454 \\
\chi 2=1.996 ; \mathrm{P}=0.158\end{array}$} & \multicolumn{3}{|c|}{$\chi 2=0.180 ; P=0.672$} \\
\hline
\end{tabular}

\section{DISCUSSION}

There are higher economic losses due to abortion, infertility, and test and slaughter policy even though many countries have plans to eradicate brucellosis. Therefore, herds should be monitored for infection. In spite of eradication programs including testing and slaughtering, vaccination, brucellosis is still a major zoonosis globally (Baek et al. 2003; Gul et al. 2013). The diagnosis of brucellosis is dependent upon indirect diagnosis through the using of serological tests such as RBPT, BAPAT, CFT, and ELISA or diagnosed directly by means of isolation and identification of the causative agents from infected animals. The problem with diagnosing brucellosis in Egypt is the lack of clear data for most vaccinated flocks, beside the randomized use of various vaccines on the same farm and overlapping between free zones and infected areas.

The presented data analyzed in Table 4 revealed that the overall seroprevalence of brucellosis in livestock examined by RBPT, BAPAT, and CFT were 11.8, 10.2, and $9.4 \%$, respectively with statistically non-significant association between recorded rates. Based on the results of RBPT, it was found that the highest prevalence was recorded in goats $(14.81 \%)$ followed by sheep $(8.89 \%)$ and lastly cattle $(6 \%)$ with statistically $(\mathrm{P}>0.05)$ non-significant 
Int J Vet Sci, 2022, 11(1): 82-90.

Table 8: Age-based seroprevalence of brucellosis in farm animals in Matrouh Province as examined by RBPT

\begin{tabular}{|c|c|c|c|c|}
\hline Farm animals & Age groups (Years) & No. & Positive & $\%$ \\
\hline \multirow[t]{2}{*}{ Cattle } & $1-<5$ & 30 & 2 & 6.67 \\
\hline & $5-<10$ & 20 & 1 & 5.00 \\
\hline $\mathrm{Chi}^{2}$ value & \multicolumn{4}{|c|}{$\chi 2=0.059 ; P=0.808$} \\
\hline \multirow{3}{*}{ Sheep } & $1-<2$ & 23 & 1 & 4.35 \\
\hline & $2-<3$ & 44 & 4 & 9.09 \\
\hline & $\geq 3$ & 113 & 11 & 9.73 \\
\hline $\mathrm{Chi}^{2}$ value & \multicolumn{4}{|c|}{$\chi 2=0.688 ; P=0.709$} \\
\hline \multirow[t]{3}{*}{ Goats } & $1-<4$ & 93 & 21 & 22.58 \\
\hline & $4-<8$ & 156 & 17 & 10.90 \\
\hline & $\geq 8$ & 21 & 2 & 9.52 \\
\hline $\mathrm{Chi}^{2}$ value & \multicolumn{4}{|c|}{$\chi 2=6.807 ; P=0.033$} \\
\hline Total $\mathrm{Chi}^{2}$ value & & & & \\
\hline
\end{tabular}

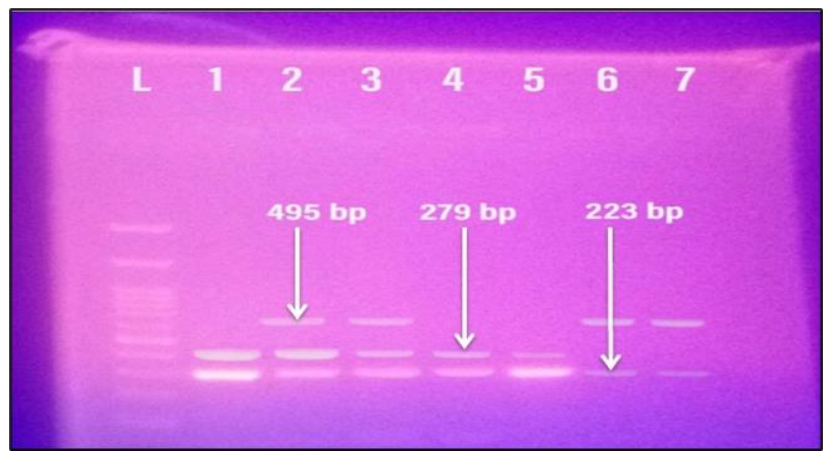

Fig. 2: PCR products of bcsp31 gene (223bp) specific for genus Brucella, IS711 element downstream of BMEI1162 gene (279bp) specific for B. melitensis, and IS711 element downstream of the alkB gene (495bp) specific for B. abortus extracted from the whole blood samples of farm animals (cattle, sheep, and goats). L: 50 bp molecular weight DNA ladder with a size range of 501500 bp. Lane 1 $\rightarrow$ 7: positive for BCSP $31 \mathrm{KDa}$ gene specific for genus Brucella extracted from whole blood samples of farm animals (camels, sheep, and goats). Lane 1: Positive for BMEI1162 gene specific for $B$. melitensis strains extracted from whole blood samples of sheep. Lane 2: Positive for both BMEI1162 gene specific for $B$. melitensis strains and alkB gene specific for $B$. abortus strains extracted from the whole blood samples of sheep. (Mixed infection). Lane 3: Positive for both BMEI1162 gene specific for $B$. melitensis strains and alkB gene specific for $B$. abortus strains extracted from the whole blood samples of goat. (Mixed infection). Lane 4 and 5: Positive for BMEI1162 gene specific for B. melitensis strains extracted from the whole blood samples of goats. Lane 6 and 7: Positive for alkB gene specific for $B$. abortus strains extracted from the whole blood samples of cattle.

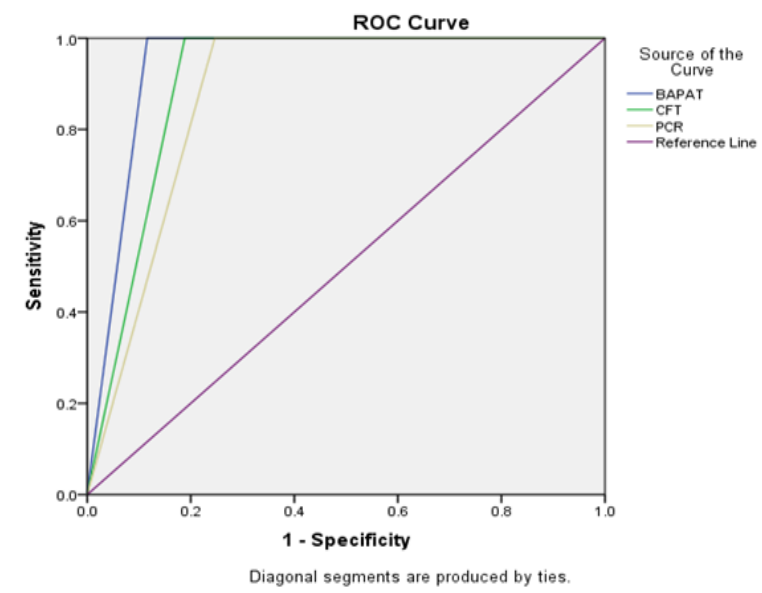

Fig. 3: Sensitivity and specificity of BAPAT, CFT, and PCR in comparing with RBPT as a gold standard technique. association. These results were close to those reported by Haggag et al. (2016) who deduced that the total brucellosis seroprevalence in ruminants by RBPT was $6.4 \%$ where the seroprevalence of Brucella antibodies in the examined serum samples of cattle, sheep, and goats was 6, 6, and 7\%, respectively. On contrary, it disagreed with Saeed et al. (2019) who found that cattle prevalence was higher than that of sheep and goats (3.8, 3.4, and 1.8\%, respectively). This could be due to the higher cattle population in Punjab, Pakistan. On the other hand, Matrouh is characterized by the higher caprine and ovine populations over bovine population.

The BAPAT based seroprevalence of brucellosis was also tabulated in Table 4 and showed that it was 4, 7.78 and $12.96 \%$ in cattle, sheep, and goats, respectively. This result was near to that obtained by Salem et al. (2016) (9.6, 10.7, and $9.6 \%$ in cows, sheep, and goats, respectively). While it was lower than that obtained by Hosein et al. (2017) (77. $3 \%$ in bovine) who carried out the screening BAPAT upon already infected farm only $(n=141)$ suffered from clinical signs of brucellosis and the results were 109 out of 141 animals were seropositive.

The CFT based seroprevalence was 4, 7.2, and $11.85 \%$ in cattle, sheep, and goats, respectively. This result was near to that obtained by Salem et al. (2016) (9.3\%, 10.3\%, and $10.3 \%$ in cows, sheep, and goats, respectively) and Diab et al. (2018) (10.56\% in sheep), Ramadan et al. (2019) $(8.36 \%$ in cattle). While it is extremely lower than that obtained by Hosein et al. (2017) (73.76\% in bovine) who conducted the CFT upon already infected farm only $(n=141)$ suffered from clinical signs of brucellosis and the results were 104 out of 141 animal were seropositive (i.e. the test wasn't carried out on free herds).

The results obtained by PCR were also tabulated in Table 4 and showed that it was 2, 6.67, and $11.11 \%$ in cattle, sheep, and goats, respectively. The lower molecular results than serological results have been agreed by results obtained by Saddique et al. (2019) who found that only $5.8 \%$ of samples were positive by PCR versus RBPT $(10.1 \%)$ and Shahzad et al. (2017) who found that only two samples were positive for Brucella through molecular diagnosis out of 18 specimens confirmed through competitive ELISA. On contrary, it disagreed with Gwida et al. (2016) who found that $36.96 \%$ of the tested specimens $(n=95)$ were seronegative but tested PCR positive in which B. abortus was the only recognized species.

Concerning cattle, the seroprevalence of brucellosis in cattle was observed to be 6,4 , and $4 \%$ by RBPT, BAPAT, and CFT, respectively. The result obtained by RBPT (6\%) 
Int J Vet Sci, 2022, 11(1): 82-90.

Table 9: Seroprevalence of brucellosis in farm animals as examined by RBPT in relation to locality in Matrouh Province

\begin{tabular}{|c|c|c|c|c|c|c|c|c|c|}
\hline & \multicolumn{3}{|c|}{ Cattle } & \multicolumn{3}{|c|}{ Sheep } & \multicolumn{3}{|c|}{ Goats } \\
\hline & No. & $+\mathrm{ve}$ & $\%$ & No. & $+\mathrm{ve}$ & $\%$ & No. & $+\mathrm{ve}$ & $\%$ \\
\hline Marsa Matrouh & 25 & 1 & 4.00 & 50 & 3 & 6.0 & 41 & 4 & 9.76 \\
\hline El-Hamam & 6 & 1 & 16.7 & 10 & 1 & 10.0 & 1 & 0 & 0.00 \\
\hline Al-Negela & 0 & 0 & 0.00 & 0 & 0 & 0.00 & 58 & 3 & 5.17 \\
\hline El-Dabaa & 19 & 1 & 5.26 & 80 & 10 & 12.5 & 170 & 33 & 19.4 \\
\hline Fuka & 0 & 0 & 0.00 & 33 & 1 & 3.03 & 0 & 0 & 0.00 \\
\hline Sidi-Barrani & 0 & 0 & 0.00 & 7 & 1 & 14.3 & 0 & 0 & 0.00 \\
\hline Total & 50 & 3 & 6.0 & 180 & 16 & 8.89 & 270 & 40 & 14.8 \\
\hline $\begin{array}{l}\text { Chi }{ }^{2} \text { value } \\
\text { Total } \mathrm{Chi}^{2} \text { value }\end{array}$ & \multicolumn{3}{|c|}{$\chi 2=1.406 ; \mathrm{P}=0.495$} & \multicolumn{3}{|c|}{$\begin{array}{c}\chi^{2}=3.469 ; \mathrm{P}=0.483 \\
\chi 2=13.098 ; \mathrm{P}=0.022\end{array}$} & \multicolumn{3}{|c|}{$\chi^{2}=8.125 ; \mathrm{P}=0.043$} \\
\hline
\end{tabular}

was equal to that obtained by Muma et al. (2012) (6.0\%), and near to that obtained by Assenga et al. (2015) (6.8\%), and Awah-Ndukum et al. (2018) (3.4\%). On the other hand, it was higher than that recorded by Salama (2019) (1.44\%). On contrary, it was lower than that recorded by Abdalla and Hamid (2012) (19.7\%), Bertu et al. (2012) (20.1\%), Zolzaya et al. (2014) (16.0\%), Ghoneim et al. (2014) (18.5\%), Madut et al. (2018) (31\%), Ramadan et al. (2019) $(8.36 \%)$, and Khan et al. (2020) (12.53\%). The variation in the prevalence of brucellosis in cattle may be due to animal population, vaccination status, susceptibility, and the hygienic measures applied in each locality (Abdalla and Hamid 2012; Ramadan et al. 2019).

The seroprevalence of brucellosis in sheep was 8.89, 7.78 , and $7.2 \%$ by RBPT, BAPAT, and CFT, respectively. The result obtained by RBPT $(8.89 \%)$ was higher to that obtained by Ashenafi et al. (2007) (3.2\%) and Zolzaya et al. (2014) (6.2\%). By contrast, it was below that of Hegazy et al. (2011) (12.2\%), Selim et al. (2015) (12\%), Abdelbaset et al. (2018) (15.87\%), and Diab et al. (2018) $(11 \%)$ and was extremely lower to that observed by Kaoud et al. (2010) (26.66\%), Musallam et al. (2015) (34.3\%), and Nofal et al. (2017) (34.5\%). This gap could be because they tested large number of herds particularly those lacking the hygienic practices resulting in high seroprevalence.

The seroprevalence of brucellosis in goats was 14.81, 12.96, and $11.85 \%$ by RBPT, BAPAT, and CFT, respectively. The obtained result by RBPT (14.81\%) was near to that recorded by Hegazy et al. (2011) (11.3\%), while it was higher than that recorded by Ashenafi et al. (2007) (5.8\%), Megersa et al. (2011) (1.9\%), Asmare et al. (2013) (1.9\%), Zolzaya et al. (2014) (5.2\%), Selim et al. (2015) (6.4\%) and Assenga et al. (2015) (1.6\%). On contrary, it was lower than that recorded by Kaoud et al. (2010) (18.88\%), Musallam et al. (2015) (34.3\%), and Nofal et al. (2017) (61.4\%).

Serological evidence of brucellosis in goats may throw the light upon the dangerous role played by goats in the continuous spreading of brucellosis to other livestock as well as a human being throughout the year in Matrouh Province so strict control measures must be followed to avoid risks attributed to rearing of the goats.

The results obtained, as illustrated in Table 5, indicate that the highest infection rate with $B$. abortus was observed in cattle $(33.3 \%)$. On contrary, the highest level of infection with $B$. melitensis was observed in sheep and goats $(62.5$ and $65 \%$, respectively). However, mixed infection with different Brucella species also occurs. These findings are in line with the results of Patel et al. (2017) who observed that out of 15 genus specific positive samples, 12 samples amplified specific gene (IS711) of B. abortus within blood samples of cattle and camels and 3 samples amplified specific universal gene outer membrane protein 31 (omp31) of B. melitensis and Imtiaz et al. (2018) who demonstrated a higher prevalence of B. abortus in Pakistan. On the other hand, it disagreed with that obtained by Saeed et al. (2019) who found that B. melitensis specific genes were detected in all blood samples of cattle, buffaloes, sheep, and goats seropositive samples $(n=35)$; However, none of the seropositive samples tested positive for $B$. abortus. Moreover, disagreed with Gwida et al. (2016) who found that $36.96 \%$ of the samples analyzed $(n=95)$ were seronegative but tested PCR positive where only B. abortus strain was identified. In addition, Rahman et al. (2020) who observed that no $B$. melitensis genes could be amplified from animal blood samples while only two samples $(6.45 \%)$ of 31 animal samples investigated were positive for bcsp31 gene by multiplex PCR assay. These variations in the detected strains were due to the different species specific of brucella according to locality.

Results obtained in Fig. 2 showed that amplification of target gene of Brucella genus (bcsp31 gene) yielding an amplicon size of 223bp as examined by Zerva et al. (2001). While amplification of target gene of B. abortus (alkB gene) yielding an amplicon size of 495bp as examined by Song et al. (2019) and amplification of target gene of $B$. melitensis (BMEI1162 gene) yielding an amplicon size of 279bp as examined by Mutnal et al. (2007). It was clear that the PCR test was a low sensitive and highly specific diagnostic method detects Brucella in animals' blood samples. Similarly, Probert et al. (2004); Gwida et al. (2016); Saeed et al. (2019); and Saddique et al. (2019) used the same primer pairs for detection of Brucella by using bcsp31 gene specific for genus Brucella, IS711element downstream of BMEI1162 gene specific for B. melitensis, and IS711 element of the alkB gene specific for B. abortus strain.

The results obtained in Table 6 and Fig. 3 showed that the sensitivity of BAPAT, CFT, and PCR in the diagnosis of brucellosis in farm animals was $88.4,81.16$, and $75.36 \%$, respectively, while the specificity of all tests was $100 \%$ as compared with that of the RBPT as a gold standard. These findings were nearly identical to those obtained by Hosein et al. (2017) who illustrated that the relative sensitivity and the relative specificity of BAPAT, RBPT, and CFT were (98.04\% and $76.92 \%),(94.33 \%$ and $85.71 \%)$, and $(93.46 \%$ and $88.23 \%$ ), respectively. The area under the curve for BAPAT, CFT, and PCR was 0.942, 0.906, and 0.877, respectively. That was nearly similar to Abdel-Hamid et al. (2017) who estimated that receiver operating characteristic (ROCs) curves and area under (AUCs) the curve were very good, either equal to or closer to 0.9 .

Sex-based seroprevalence of brucellosis in cattle depending on the results of RBPT was recorded in Table 7. 
It revealed that the prevalence of brucellosis was 5.41 and $7.69 \%$ in females and males, respectively. Chi-square analysis of the obtained result demonstrated a nonsignificant relation $\left(\mathrm{Chi}^{2}\right.$ value $\left.=0.089, \mathrm{P}>0.05\right)$ between sex and bovine brucellosis prevalence. This result disagreed with Assenga et al. (2015) and Rahman et al. (2011) who found a significantly higher seroprevalence within females than males bovine and Madut et al. (2018) who documented a higher prevalence in females $(32.5 \%)$ than males $(30.4 \%)$. On contrary, it was in harmony with that of Ashenafi et al. (2007) and Gul et al. (2014) who found that sex-related brucellosis seroprevalence in cattle was insignificant.

Sex-related brucellosis seroprevalence in sheep depending upon the findings of RBPT was recorded in Table 7. It was found that 11 out of 108 females tested positive (10.2\%), while 5 out of 72 males tested positive $(6.94 \%)$. Chi-square analysis of the obtained result showed a non-significant relationship $\left(\mathrm{Chi}^{2}\right.$ value $\left.=0.560, \mathrm{P}>0.05\right)$ between sex and the prevalence of brucellosis in sheep. This result agreed with Ashenafi et al. (2007); Gul et al. (2014); and Abdelbaset et al. (2018) who found that sexrelated seroprevalence of brucellosis in sheep was nonsignificant and higher in females.

Sex-based seroprevalence of brucellosis in goats depending on the results of RBPT was recorded in Table 7. It revealed that the prevalence was $15.35 \%$ in females and was $13.24 \%$ in males. Chi-square analysis of the obtained result showed a non-significant relationship $\left(\mathrm{Chi}^{2}\right.$ value $=0.180, \mathrm{P}>0.05$ ) between sex and the brucellosis prevalence in goats. This result approved with Gul et al. (2014) who found that sex-based brucellosis seroprevalence in goats was negligible. The higher infection rate among ewes and goats will be due to infection within the female reproductive tract providing a potential habitat for the organism to propagate and multiply.

Seroprevalence of brucellosis in cattle in relation to age depending on the results of RBPT was tabulated in Table 8. It clarified that the seroprevalence in the age group $(5-<10$ years) $(5 \%)$ lower than that of the age group $(1-<5$ years) $(6.67 \%)$. Statistical analysis showed non-significant association $\left(\mathrm{Chi}^{2}\right.$ value $\left.=0.059, \quad \mathrm{P}>0.05\right)$ between brucellosis prevalence and age of in bovine. This disagreed with Salama (2019) who observed that cattle older than 3 years had the highest seroprevalence (2.77\%), Muma et al. (2012) who deduces that age was associated with seropositivity of Brucella, and Assenga et al. (2015) who observed that there was a statistically significant difference in seroprevalence between mature cattle and young one.

Age-based brucellosis seroprevalence of sheep was depending on results of RBPT was found in Table 8. It shown that the greatest seroprevalence was observed in the age group equal to or over 3 years $(9.73 \%)$ followed by (2$<3$ years $)(9.09 \%)$ then the age group $(1-<2$ years) $(4.35 \%)$ and statistical analysis showed non-significant relationship $\left(\mathrm{Chi}^{2}\right.$ value $\left.=0.688, \mathrm{P}>0.05\right)$ between brucellosis prevalence and age. This finding correlated with the surveillance of Ashenafi et al. (2007) who observed a higher prevalence rate $(5.3 \%)$ was in mature animals than $(1.6 \%)$ in younger sheep. On contrary, it disagreed with Abdelbaset et al. (2018) and Diab et al. (2018) who noted that there was a significant association between infection rate and age groups of sheep $(\mathrm{P}<0.01)$.
The higher infectivity in the older sheep will be due to their advanced age, as the organism may remain dormant or chronic indefinitely before manifesting as clinical disease. Older animals are also more likely to develop the infection and come into contact with other animals. On the other words, the susceptibility of animals is increased after sexual maturity because erythritol and sex hormones boost the growth of Brucella organisms. Younger animals tend to be more resistant to Brucella infections; however, latent infections can occur in these animals (Gul et al. 2013).

Seroprevalence of brucellosis depends upon age in goats based on the results of RBPT was found in Table 8 . It was observed that the greatest seroprevalence was demonstrated in the age group $(1-<4$ years old $)(22.58 \%)$ followed by the age group $(4-<8$ years old) $(10.90 \%)$ then the age group ( $\geq 8$ years old) $(9.52 \%)$ and statistical analysis showed significant association $\left(\mathrm{Chi}^{2}\right.$ value $\left.=0.807, \mathrm{P}<0.05\right)$ between age and the brucellosis prevalence in goats. The greater prevalence rate of brucellosis among the age group $1-<4$ years old may be due to the Sannen breed that more susceptible to brucellosis than the other breeds fall within this age range. This result coherent to that obtained by Olufemi et al. (2018) who found a significant relationship between the different age groups.

Seroprevalence of brucellosis in farm animals through RBPT concerning locality in Matrouh Province was recorded in Table 9. The seroprevalence of brucellosis in cattle has been found to be highest in El-Hamam (16.7\%) followed by El-Dabaa (5.26\%) then Marsa Matrouh (4\%). while the results of sheep revealed that the highest prevalence was observed in Sidi-Barrani (14.3\%) followed by El-Dabaa (12.5\%) then El-Hamam (10\%) and Marsa Matrouh (6\%) and finally Fuka (3.03\%). Concerning goats, it was found that that the highest prevalence was observed in El-Dabaa (19.4\%) followed by Marsa Matrouh (9.76\%). On contrary to other species, Statistical analysis showed a significant association between brucellosis seroprevalence among goats and locality in Matrouh Province. These results in harmony with that obtained by Diab et al. (2018) who recorded a significant $(\mathrm{P}<0.01)$ relationship between locality and prevalence in sheep.

It was vibrant that there was a greater prevalence of brucellosis in El-Dabaa and El-Hamam that are nomadic areas in Matrouh Province with a high population of sheep and goats that may be considered the source of infection to other livestock. This finding was similar to that obtained by Rabah et al. (2020) who found that El-Dabaa was recorded the highest camels' seroprevalence. In addition, the social pattern of this area may explain the lack of awareness about the disease and its control strategy so great efforts are needed to be done by the official and governmental authorities to involve the population in any control strategy.

\section{Conclusion}

The recorded results in the current study throw the light upon the role of ruminant in Matrouh Province, Western Egypt in the epidemiological pattern of brucellosis. Under the conditions of this study and based on the available data obtained, it is concluded that brucellosis is still remaining a problem in farm animals in Matrouh Province where brucellosis is more prevalent in goats as compared to the other farm animals and also mature animals are at higher risk as compared to younger ones. 


\section{Author's Contribution}

MAN and EK conceptualized the idea of the research. IMR collected the Samples. MAN, EK, MMK, and IMR performed the tests and collected the data. MAN, EK, and IMR analyzed the data. MAN, EK, and IMR wrote and edited the manuscript. MAN, IMR, MMK, and EK made funds available.

\section{Acknowledgements}

The authors are thankful to Animal hygiene and Zoonoses Department (Faculty of Veterinary Medicine, Alexandria University, Egypt) and Microbiology Department (Faculty of Veterinary Medicine, Matrouh University, Egypt) for their co-operation during the research period.

\section{REFERENCES}

Abdalla A and Hamid ME, 2012. Comparison of conventional and non-conventional techniques for the diagnosis of bovine brucellosis in Sudan. Tropical Animal Health and Production 44: 1151-1155. https://doi.org/10.1007/s11250-011-0051-7

Abdel-Hamid NH, Ismail RI, Beleta EI and Ghobashy HM, 2017. Development and Validation of Protein G Based Indirect ELISA Versus Lateral Flow Assay as Screening Immunoassays for brucellosis in Camels (Camelus Dromedarius). Alexandria Journal for Veterinary Sciences 53: 11-20. https://doi.org/10.5455/ajvs.256953

Abdelbaset AE, Abushahba MF, Hamed MI and Rawy MS, 2018. Sero-diagnosis of brucellosis in sheep and humans in Assiut and El-Minya governorates, Egypt. International Journal of Veterinary Science and Medicine 6: S63-S67. https://doi.org/10.1016/j.ijvsm.2018.01.007

Adam M and Moss R, 1995. Food Microbiology the Royal Society of Chemistry Thomas Garden House Science Park. Cambridge CB 40: 156-218.

Aldomy F, Alkhawaldeh M and Younis I, 2009. Immune responses of goats (Shami breed) to vaccination with a full, reduced and conjunctival dose of brucevac (Brucella melitensis Rev. 1) vaccine. Pakistan Veterinary Journal 29: 149-153.

Arif S, Heller J, Hernandez-Jover M, McGill DM and Thomson PC, 2018. Evaluation of three serological tests for diagnosis of bovine brucellosis in smallholder farms in Pakistan by estimating sensitivity and specificity using Bayesian latent class analysis. Preventive Veterinary Medicine 149: 21-28. https://doi.org/10.1016/j.prevetmed.2017.11.002

Ashenafi F, Teshale S, Ejeta G, Fikru R and Laikemariam Y, 2007. Distribution of brucellosis among small ruminants in the pastoral region of Afar, eastern Ethiopia. Scientific and technical review (International Office of Epizootics) 26: 731. https://doi.org/10.20506/rst.26.3.1781

Asmare K, Megersa B, Denbarga Y, Abebe G, Taye A, Bekele J, Bekele T, Gelaye E, Zewdu E, Agonafir A, Ayelet G and Skjerve E, 2013. A study on seroprevalence of caprine brucellosis under three livestock production systems in southern and central Ethiopia. Tropical Animal Health and Production 45: 555-560. https://doi.org/10.1007/s11250012-0258-2

Assenga JA, Matemba LE, Muller SK, Malakalinga JJ and Kazwala RR, 2015. Epidemiology of Brucella infection in the human, livestock and wildlife interface in the KataviRukwa ecosystem, Tanzania. BMC Veterinary Research 11: 189. https://doi.org/10.1186/s12917-015-0504-8

Awah-Ndukum J, Mouiche MMM, Kouonmo-Ngnoyum L, Bayang HN, Manchang TK, Poueme RSN, Kouamo J, NguNgwa V, Assana E and Feussom KJM, 2018. Seroprevalence and risk factors of brucellosis among slaughtered indigenous cattle, abattoir personnel and pregnant women in
Ngaoundéré, Cameroon. BMC Infectious Diseases 18: 611. https://doi.org/10.1186/s12879-018-3522-x

Baek B, Lim C, Rahman M, Kim CH, Oluoch A and Kakoma I, 2003. Brucella abortus infection in indigenous Korean dogs. Canadian Journal of Veterinary Research 67: 312.

Bertu WJ, Gusi AM, Hassan M, Mwankon E, Ocholi RA, Ior DD, Husseini BA, Ibrahim G, Abdoel TH and Smits HL, 2012. Serological evidence for brucellosis in Bos indicus in Nigeria. Tropical Animal Health and Production 44: 253258. https://doi.org/10.1007/s11250-011-0011-2

Corbel MJ, 2006. Brucellosis in humans and animals. World Health Organization.

Diab MS, Elnaker YF, Ibrahim NA, Sedeek EK and Zidan SAA, 2018. Seroprevalence and Associated Risk Factors of brucellosis in Sheep and Human in Four Regions in Matrouh Governorate, Egypt. World's Veterinary Journal 8: 65-72.

Eltholth M, Hegazy YM, El-Tras WF, Bruce M and Rushton J, 2017. Temporal analysis and costs of ruminant brucellosis control programme in Egypt between 1999 and 2011. Transboundary and Emerging Diseases 64: 1191-1199. https://doi.org/10.1111/tbed.12491

Farahat L, Abd-El-Azeem K, El Menisy A and Mahrouse A, 2019. Preparation of buffered acidified plate antigen from Brucella abortus strain 19. Benha Veterinary Medical Journal 36: 43-50.

Ghoneim N, Zeedan G, Ghazy A and Abdalhamed A, 2014. Molecular and Serological detection of the most common Brucella species infection in bovine and human in Egypt. International Journal of Advanced Research 2: 217-26.

Gul ST, Khan A, Ahmad M and Hussain I, 2013. Seroprevalence of Brucellosis and associated hematochemical changes in pakistani horses. Pakistan Journal of Agricultural Sciences 50: 745-750.

Gul ST, Khan A, Rizvi F and Hussain I, 2014. Sero-prevalence of brucellosis in food animals in the Punjab, Pakistan. Pakistan Veterinary Journal 34: 454-458.

Gwida M, El-Ashker M, Melzer F, El-Diasty M, El-Beskawy M and Neubauer H, 2016. Use of serology and real time PCR to control an outbreak of bovine brucellosis at a dairy cattle farm in the Nile Delta region, Egypt. Irish Veterinary Journal 69: 3. https://doi.org/10.1186/s13620-016-0062-9

Haggag YN, Samaha HA, Nossair MA and Mohammad HS, 2016. Monitoring of Ruminant Sera for the Presence of Brucella Antibodies in Alexandria Province. Alexandria Journal for Veterinary Sciences 51: 290-295. https://doi.org/10.5455/ ajvs. 218332

Hegazy YM, Moawad A, Osman S, Ridler A and Guitian J, 2011. Ruminant brucellosis in the Kafr El Sheikh Governorate of the Nile Delta, Egypt: prevalence of a neglected zoonosis. PLOS Neglected Tropical Diseases 5: e944. https://doi.org/ 10.1371/journal.pntd.0000944

Hosein H, Rouby S, Menshawy A and AbdAl-Ghany A, 2017. Sensitivity and specificity of the commonly used diagnostic procedures of bovine brucellosis. Veterinary Sciences: Research and Reviews 3: 45-52.

Imtiaz W, Khan A, Gul ST, Saqib M, Saleemi MK, Shahzad A, Dong J, Hussain R, Shen M and Du XX, 2018. Evaluation of DNA vaccine encoding BCSP31 surface protein of Brucella abortus for protective immunity. Microbial Pathogenesis 125: 514-520. https://doi.org/10.1016/j.micpath.2018.10. $\underline{016}$

Kaoud H, Zaki MM, El-Dahshan A and Nasr SA, 2010. Epidemiology of brucellosis among farm animals. Nature and Science 8: 190-197.

Khan UD, Khan A, Gul ST, Saleemi MK and Du XX, 2020. Seroprevalence of brucellosis in cattle (Bos taurus) kept in peri urban areas of Pakistan. Agrobiological Records 1: 610. https://doi.org/10.47278/journal.abr/2020.003

Madut NA, Muwonge A, Nasinyama GW, Muma JB, Godfroid J, Jubara AS, Muleme J and Kankya C, 2018. The seroprevalence of brucellosis in cattle and their herders in Bahr 
el Ghazal region, South Sudan. PLOS Neglected Tropical Diseases 12: e0006456. https://doi.org/10.1371/journal. pntd.0006456

Megersa B, Biffa D, Abunna F, Regassa A, Godfroid J and Skjerve E, 2011. Seroprevalence of brucellosis and its contribution to abortion in cattle, camel, and goat kept under pastoral management in Borana, Ethiopia. Tropical Animal Health and Production 43: 651-656. https://doi.org/ 10.1007/s11250-010-9748-2

Morata P, Queipo-Ortuno MI, Reguera JM, García-Ordonez MA, Cárdenas A and Colmenero JD, 2003. Development and evaluation of a PCR-enzyme-linked immunosorbent assay for diagnosis of human brucellosis. Journal of Clinical Microbiology 41: 144-148. https://doi.org/10.1128/JCM. 41.1.144-148.2003

Muma JB, Pandey GS, Munyeme M, Mumba C, Mkandawire E and Chimana HM, 2012. Brucellosis among smallholder cattle farmers in Zambia. Tropical Animal Health and Production 44: 915-920. https://doi.org/10.1007/s11250011-9987-X

Musallam II, Abo-Shehada MN and Guitian J, 2015. Knowledge, attitudes, and practices associated with brucellosis in livestock owners in Jordan. The American Journal of Tropical Medicine and Hygiene 93: 1148-1155. https://doi.org/10.4269/ajtmh.15-0294

Mutnal MB, Purwar S, Metgud SC, Nagmoti MB and Patil CS, 2007. PCR confirmation of cutaneous manifestation due to Brucella melitensis. Journal of Medical Microbiology 56: 283-285. https://doi.org/10.1099/jmm.0.46927-0

Nofal AS, El-Leboudy AA, El-Makarem HSA and El-Rahman AHA, 2017. Prevalence of Brucella Organism in Milk and Serum Samples of Some Lactating Dairy Animals. Alexandria Journal for Veterinary Sciences 55: 19-24. https://doi.org/10.5455/ajvs.278394

Norusis M, 2008 SPSS 16.0 advanced statistical procedures companion, Prentice Hall Press.

O'Leary S, Sheahan M and Sweeney T, 2006. Brucella abortus detection by PCR assay in blood, milk and lymph tissue of serologically positive cows. Research in Veterinary Science 81: 170-176. https://doi.org/10.1016/j.rvsc.2005.12.001

Olufemi OT, Dantala DB, Shinggu PA, Dike UA, Otolorin GR, Nwuku JA, Baba-Onoja EB, Jatau TD and Amama FI, 2018. Seroprevalence of Brucellosis and Associated Risk Factors among Indigenous Breeds of Goats in Wukari, Taraba State, Nigeria. Journal of Pathogens 2018: 5257926-5257926. https://doi.org/10.1155/2018/5257926

Patel KB, Chauhan H, Patel B, Patel S, Shrimali M, Kala J, Modi AN, Manish R, Patel MA and Patel AC, 2017. Clinicoseroepidemiology and molecular characterization of brucellosis in animals. International Journal of Current Microbiology and Applied Sciences 6: 222-231. https://doi.org/10.20546/ijcmas.2017.604.026

Probert WS, Schrader KN, Khuong NY, Bystrom SL and Graves MH, 2004. Real-time multiplex PCR assay for detection of Brucella spp., B. abortus, and B. melitensis. Journal of Clinical Microbiology 42: 1290-1293. https://doi.org/ 10.1128/JCM.42.3.1290-1293.2004

Rabah I, Nossair M, Abdou E, Elkamshishi M and Khalifa E, 2020. Serological and Molecular Epidemiological Study on Brucellosis in Camels and Human in Matrouh Province. Damanhour Journal of Veterinary Sciences 4: 1-6. https://doi.org/10.5455 /DJVS.2020.34908.1030

Rahman M, Faruk M, Her M, Kim J, Kang S and Jung S, 2011. Prevalence of brucellosis in ruminants in Bangladesh. Veterinarni Medicina 56: 379-385. https://doi.org/10.17221/ 1555-VETMED

Rahman M, Rahman M, Rahman A, Hossain M, Hasan M, Rana M, Melzer F and Neubauer H, 2020. Sero-molecular epidemiology and rick factors analysis of brucellosis in human and lactating cows of military dairy farms in Bangladesh. Journal of Veterinary Medical and One Health
Research 2: 81-114. https://doi.org/10.36111/jvmohr.2020. 2(1).0018

Ramadan ES, Nassar NR, Ibrahim IG and Zayed AF, 2019. Epidemiological and Zoonotic Surveillance of brucellosis in Beni-Suef Governorate. Alexandria Journal for Veterinary Sciences 61: 22-31. https://doi.org/10.5455/ajvs.39738

Refai M, 2003. Brucellosis in animals and man in Egypt. Egyptian Journal of Veterinary Sciences 37: 1-31.

Saddique A, Ali S, Akhter S, Khan I, Neubauer H, Melzer F, Khan AU, Azam A and El-Adawy H, 2019. Acute Febrile Illness Caused by Brucella abortus Infection in Humans in Pakistan. International Journal of Environmental Research and Public Health 16: 4071. https://doi.org/10.3390/ ijerph16214071

Saeed U, Ali S, Khan TM, El-Adawy H, Melzer F, Khan AU, Iftikhar A and Neubauer H, 2019. Seroepidemiology and the molecular detection of animal brucellosis in Punjab, Pakistan. Microorganisms 7: 449. https://doi.org/10.3390/ microorganisms 7100449

Salama AA, 2019. Serological and Molecular Diagnosis of Bovine brucellosis in Menoufia Province. Journal of Current Veterinary Research 1: 115-126. https://doi.org/10.21608/ JCVR.2019.10696.1002

Salem L, Khalifa NO and Moustafa SM, 2016. Sero-diagnosis of brucellosis in Gharbiya governorate, Egypt. Benha Veterinary Medical Journal 31: 10-16. https://doi.org/ $\underline{10.21608 / B V M J .2016 .31211}$

Selim A, Gaber A and Moustafa A, 2015. Diagnosis of brucellosis in Ruminants in Kafr El-Sheikh governorate, Egypt. International Journal of Advanced Research 3: 345-350.

Shahzad A, Khan A, Khan MZ and Saqib M, 2017. Seroprevalence and molecular investigations of brucellosis in camel of selected regions of Pakistan. Thai Journal of Veterinary Medicine 47: 207-215.

Shahzad A, Du XX, Khan A, Khan MZ, Saqib M, Gul MT, Saleemi MK and Bayi J, 2018. Patho-morphological valuation of acute infection of Brucella melitensis in goats. Pakistan Veterinary Journal 38: 341-346. http://dx.doi.org/ 10.29261/pakvetj/2018.099

Song K, Li Z, Kim T.-H, Wang X, Bu Z, Li S, Hwang HJ and Kim $\mathrm{JH}, 2019$. Ultra-fast detection and differentiation of Brucella genus bacteria, B. abortus, B. melitensis, and B. suis, using multiplex convection polymerase chain reaction. Japanese Journal of Veterinary Research 67: 51-59. https://doi.org/ 10.14943/jivr.67.1.51

Sotnikov DV, Berlina AN, Zherdev AV, Eskendirova SZ, Mukanov KK, Ramankulov YM, Mukantayev KN and Dzantiev BB, 2019. Immunochromatographic serodiagnosis of brucellosis in cattle using gold nanoparticles and quantum dots. International Journal of Veterinary Science 8: 28-34.

Welay GM, Tedla DG, Teklu GG, Weldearegay SK, Shibeshi MB, Kidane HH, Gebrezgiabher BB and Abraha TH, 2018. A preliminary survey of major diseases of ruminants and management practices in Western Tigray province, northern Ethiopia. BMC Veterinary Research 14: 293. https://doi.org/ 10.1186/s12917-018-1621-y

Wanger A, Chavez V, Huang R, Wahed A, Dasgupta A and Actor JK, 2017. Microbiology and molecular diagnosis in pathology: a comprehensive review for board preparation, certification and clinical practice. Elsevier, pp: 298.

Zerva L, Bourantas K, Mitka S, Kansouzidou A and Legakis N, 2001. Serum is the preferred clinical specimen for diagnosis of human brucellosis by PCR. Journal of Clinical Microbiology 39: 1661-1664. https://doi.org/10.1128/ JCM.39.4.1661-1664.2001

Zolzaya B, Selenge $T$, Narangarav $T$, Gantsetseg D, Erdenechimeg D, Zinsstag J and Schelling E, 2014 Representative seroprevalences of human and livestock brucellosis in two Mongolian provinces. EcoHealth 11: 356371.https://doi.org/10.1007/s10393-014-0962-7 